\title{
The Tourist Municipality In The Tourism Regulation Branch Of The Spanish Legislation
}

\author{
Antonio Villanueva-Cuevas, Ph.D., University of Castilla-La Mancha, Spain
}

\begin{abstract}
In the branch of the Spanish legislation that regulates local government, there may be a possibility of articulating a special legal status for those municipalities that have certain specific characteristics, which include intense tourism activity. These municipalities are characterized by having tourism levels that are quite high, which has led to, among other consequences, the existence of many second homes, hotels and other superior lodging establishments, which may include primary residences, and has led to the majority of their populations working mainly in the tourism sector. All of these special characteristics result not only in economic benefits for these municipalities; they also lead to a full range of problems for the aforementioned locales. Among these problems is, for example, the need to provide a high number of obligatory public services, which would be carried out by local residents, including cleaning, protection of citizens, public transport, health services, etc. In many instances, the costs for these services are the direct responsibility of municipal budgets, and in the last instance, it is the locals themselves who pay by way of local taxes. In order to solve these problems, several self-governing laws for tourism structure have anticipated the existence of "tourist municipalities", which establish certain requisites for their declaration, and which detail a set of obligations and laws for said municipalities.
\end{abstract}

Keywords: Tourism; Municipalities; Environment; Public Services

\section{INTRODUCTION}

ince the 1950s, tourism has become the most important activity in Spain, economically speaking. This is proven by impressive numbers, which led this country to be ranked in 2010 (the latest year with consolidated figures) as the world's fourth tourist destination, with 52.7 million tourists received that year. It is the second destination when it comes to revenue generated by these visits, at 52.525 million dollars (World Tourism Organization, WTO Outlook for International Tourism, 2011 Edition), a fact which may be even more significant than the previous one, and that which, according to the tourist entrance figures that have been calculated for 2011, will be much higher for that year.

Still, the repercussions of tourism activity far outweigh those which are merely economic. Receptive locales, which are often located along the coast, the main destination for the immense majority of entering tourists and tourist movement, are the site at certain times of year of a more or less controlled "invasion" of tourists who radically modify local economic, social, cultural, urban, patrimonial and environmental circumstances. This activity requires an endless number of all kinds of services, from simple public services such as transport, water, street lights, health services and trash pickup, among others, to those that are entirely private, like lodging, restaurants and leisure spots, among others, which are notably more comprehensive than those services required by those who reside year-round in these locales. And while it may be true that these populations benefit markedly from the income generated by tourism, as do municipal treasury departments, it is also true that the cost of excess services, which does not fall to tourists, is normally covered by municipal taxes. 
In an effort to alleviate that situation, an entity known as the "tourist municipality" has sprung up in Spain. It comes from Art. 30 of Law 7/1985, from April $2^{\text {nd }}$, Local Government Regulation in Spain (hereafter referred to as LRBRL), which states that "local governmental laws in the Autonomous Communities, within the framework established in this Law, can establish special systems for small or rural municipalities, and for those with other advisable characteristics, such as historical-artistic character or the predominance of tourism, industrial and mining activity, or other similar activities".

Citing this precept, Catalonia was the first community to adjust its municipal tourism statute in Art. 72 of its Law 8/1987, from April $15^{\text {th }}$, from Catalonia's municipal and local government (ROCA ROCA and PÉREZ MARTOS, 1998). Murcia followed its lead with its Law 6/1988, from August $25^{\text {th }}$, through its local government, which also anticipated several precepts that referred to this entity (BLANQUER CRIADO, 1999), even if at first it seemed as though the Autonomous Communities were fairly reticent to utilize said entity. Currently, there are several Autonomous Communities that have anticipated the tourist municipality in their specific legislation for tourism structure, including the Canary Islands, Cantabria, Andalusia, Aragon, Navarre, Galicia, the Autonomous Community of Valencia and of course, Catalonia and Murcia.

That having been said, there are clear differences when it comes to the regulations that the aforementioned Autonomous Communities have put in place for this entity. Some simply anticipate it, without outlining its regulation (like the Canary Islands and Navarre), while others (especially the Autonomous Community of Valencia) are notable for the wide range of precepts dedicated to the subject. We will see in the following pages the characteristics and legal status that this special entity holds in the Autonomous Communities' legislation on tourism structure.

\section{THE REGULATION OF THE TOURIST MUNICIPALITY IN THE AUTONOMOUS COMMUNITIES' LEGISLATION ON TOURISM STRUCTURE.}

As we have already stated, there is a growing number of Autonomous Communities that have taken an interest in establishing specific legal status for some of their municipalities for which tourism activity is the basis of local growth, but only up to the point at which this determines and unites a variety of aspects in the life of said municipalities. However, before entering into the different ways in which these Autonomous Communities have regulated the entity, it would be helpful to indicate that, of the Communities listed above, the Canary Islands and Navarre hardly require a closer look. In the Second Additional Provision of its Law 7/1995, from April 6 ${ }^{\text {th }}$, on Tourism Structure in the Community, the Canary Islands once again includes a later draft bill that regulates this entity within its own borders, while also establishing certain bases that should serve as a guide for the subsequent draft bill. Specifically, the aforementioned Additional Provision grants a period of six months starting when the law goes into effect for the writing of the draft bill, after the most representative associations of the municipalities in the Canary Islands have been heard, and on the following bases: “...

a) There, public dominion and public services will be oriented expressly toward tourism, in agreement with what has been anticipated in the present Law.

b) Fiscal and financial measures will be recognized, which allow for services of sufficient quality.

c) Special attention will be paid to the identification of tourist areas and to the conservation and diversification of its most attractive features, both natural and urban.

d) Tourist areas which are separated from the city center will have a complementary organization where the most effective participation by locals will be made possible.

Neighborhoods classified as tourist areas will also have a complementary organization through the creation of media anticipated in the Law of Legal Status for Local Public Government in the Canary Islands for decentralized management and participation of locals. In any case, a neighborhood Council must be created if it does not already exist, as well as a Council for the tourism sector.

In any case, the participation on said Council by the sector's most representative business and social organizations will be established". 
For its part, Navarre is even more concise when it indicates the Sole Additional Provision of its Regional Law $7 / 2003$, from February $14^{\text {th }}$, on Tourism, which states that "those zones which are recognized as tourist municipalities and areas of touristic interest will be considered as such in the "Long-Term Plan of Action", referring to a subsequent statutory development for the determination of the conditions necessary for a tourist municipality to be considered as such.

Nevertheless, the rest of the Autonomous Communities cited-Cantabria, Andalusia, Aragon, Galicia, the Autonomous Community of Valencia, Catalonia and Murcia - do control the true legal status of the "tourist municipality", although we can also find differences among them, in such a way that we will split them into two large groups. Communities in the first group, which includes Cantabria, Andalusia, Aragon, Galicia, Catalonia and Murcia, establish which might be called a general system for this entity, although we must take a more individualized look at Catalonia and Galicia, whose regulation is more detailed. The second group includes only the Autonomous Community of Valencia, whose regulation is quite broad and is clearly different from that which is utilized by the other Autonomous Communities listed above. Let's begin with the general system we have just made reference to.

\section{a. Requisites for the declaration of a municipality as a tourist municipality, and the consequences of this declaration.}

As we have just stated, laws governing tourism structure in the Communities of Aragon, Cantabria, Andalusia and Murcia utilize a sort of regulation that might be understood as a general system which is applicable to this matter. In this respect, said Communities regulate two basic aspects: 1) the requisites that the municipalities have to meet in order to opt into the declaration, and 2) the consequences of said declaration, which we can put forward in general terms as being restricted to top priority access to financial aid which is lent by the Autonomous government. In spite of this, it is worth pointing out that Andalusia includes another issue to the two mentioned above, which we consider to be clearly relevant, such as the definition of "part-time population", to which we will make later reference, and the "essential finality" of the declaration of municipality of touristic interest, which is focused on the best municipal services for the tourist population (JÁIMEZ GAGO, 2010).

In this sense, it is worth indicating that the Andalusian law for tourism structure (Law 12/2009, from December $15^{\text {th }}$ ) also includes a specific definition for "tourist municipality", something that none of the other analyzed regional laws do, although the definition is made in terms that are so general that they implicitly allow us to derive a definition which is similar to that in the other regional laws. In this way, the first paragraph of Art. 6 of that law states that "all those areas that fulfill the legally established criteria, including the part-time population, numbers of visitors and tourist attractions will be considered Tourist Municipalities, and as such, will be able to apply for the declaration".

Of much greater interest than that concept, and continuing with the same Andalusian rule, is the essential finality that the declaration of tourist municipality possesses, above all because it highlights the objectives that the locale hopes to gain through this new title. Specifically, "the fomentation of quality in municipal services provided to the parttime population, through a state-assisted act of fomentation" (Art. 6, $3^{\text {rd }}$ paragraph, of the Andalusian Law on Tourism Structure) and that, if not in terms that are quite so clear, this can also be found in the rest of the cited laws, for example in Art. 39, $2^{\text {nd }}$ paragraph, letter B of the Cantabrian Law on Tourism (Law 5/1999, from March $24^{\text {th }}$ ). As you can see, from this we can conclude that, for these municipalities, the increment of the visiting population they benefit from brings with it, on the one hand, an obligation to provide the entire population (residents and visitors alike) with quality public services, with the added dimension that this brings with respect to those services that are necessary only for local residents; and on the other hand, a problem, which is the financing of these additional municipal services, for which local taxes will be clearly insufficient. The effect would mean a much higher cost to the resident population which, in fact, does not have a need for such a huge number of services.

But, now that we have taken a detailed look at the aspects above, it is worth analyzing the requisites required by the laws of the Autonomous Communities mentioned above-Aragon, Cantabria, Murcia and Andalusia-for the declaration of a Tourist Municipality. And if it is possible to find differences between them, the criteria detailed by each community are quite similar, which allows us to summarize them in the following manner: 
- First, the element which we can understand as preliminary and necessary is required-the existence of significant tourist traffic during the holiday months and other seasonal periods. On this point, only the Law from the Community of Aragon (Law 6/2003, from February $27^{\text {th }}$, on Tourism, Art. 15) establishes quantitative criteria-at least twice the permanent population-while the Communities of Cantabrian and Murcia take a much simpler approach, referring only to a considerable increase or influx in the population.

Andalusia does not allude specifically in its law on tourism structure to any quantitative element, but rather refers only to the part-time population and to the number of visitors, with no further qualifications, although subsequently, it does establish quantities in its law governing the tourist municipality (Andalusian Decree 158/2002, from May $\left.28^{\text {th }}\right)$. Still, the definition of the "part-time population" is illuminating. For this reason, in our opinion, the definition constitutes the real reason for the regulation of the tourist municipality, and in this sense, the $3^{\text {rd }}$ paragraph of Art. 6 of the Andalusian law indicates that it is "the one constituted by those who cannot claim to be citizens of the municipality, but who are part-time residents by way of tourist visit, second home or tourist lodging. The decision will be made using all evidence that is established by rule of law". It is precisely the existence of said tourist population, in significant numbers, and in the areas which are defined by Andalusian law, together with the satisfaction of the needs of this tourist population, which determines the very existence of these municipalities.

- Second, the laws regulating tourism in the Autonomous Communities listed above indicate that it is necessary to have attractions which are local and complementary, and provide lodging, thus justifying the declaration, although there is a wide range of criteria when it comes to the quantification of said attractions. On this point, Aragon is the most demanding, referring to a number which is at least twice that of houses listed on the census when compared to those which are inhabited, or of hotel beds or other lodging spaces when compared to permanent residents. Andalusia is the most flexible, with the most concise law in this respect. It alludes only to the existence of "tourist attractions" as a criteria that is required in order to apply for the declaration of tourist municipality, which makes it necessary to turn to their development statutes, cited above, for higher specificity on this point.

- Third, a great many obligatory public services are required. Other services that are especially relevant in tourism are also required, such as the need to provide tourist information offices, to cite just one example of services that are specifically related to tourists. Along these same lines, it is worth mentioning the express requirement in the laws of Murcia and Aragon in the sense that in the first instance, a significant percentage of the local budget is devoted to tourism promotion and infrastructure - which does not include the quantities reserved for local holidays - (Art. 51, $3^{\text {rd }}$ paragraph, from Law 11/1997, from December $12^{\text {th }}$, on Tourism in the Region of Murcia); and in the second instance, an important part of the budget is for obligatory municipal services, and for other services that influence tourism (Art 15, $2^{\text {nd }}$ paragraph, Letter C, from the Aragon Law previously cited).

- Fourth, municipalities are required to take special care with the protection of their natural areas and of their cultural and urban heritage, although this is nothing more than a further specification of the previous section, and as an example, in Art. 51, $3^{\text {rd }}$ paragraph, Letter D, from the Murcia Law above cited, as a condition for evaluating the declaration of a municipality as a tourist municipality, there is a requirement for the "existence of Environmental By-Laws which duly include measures for the preservation of environmental values, as well as for respect for the rights to intimacy, calm and general well-being of tourists, with a range that is determined through statutes, which must cover such aspects as health statistics, security, noise and odor control, and any other aspect that may be a result of the aforementioned goals".

- Fifth, and finally, of the regulation carried out by the autonomous standards referred to above, the need for municipal action is inferred, whether expressly or implicitly, as referred to, for example, in the two previous points, which are directed toward an improvement in the quality of tourist attractions. As an example, we might turn to Art. 39, Section 2, Letter B, from the Law on Tourism Structure in Cantabria, referred to above, which indicates that the municipality in question must develop a program for the promotion and fomentation of sustainable tourism in which quality and innovation will be aspects of utmost importance in the formulation of said program, making sure that special attention is given to the following questions: “...

- The need to develop the kind of tourism that responds to economic prospects and to requirements for environmental protection. 
- All tourism activity must have an effective impact on the improvement of quality of life for the local population, contribute to its socio-cultural enrichment and lead to the creation of good jobs.

- The maintenance of the municipality's culture, history and personality.

$\circ \quad$ The adaptation of urbanism and the edification of the local landscape and the integral structure of patrimony.

- The existence of strategic water reserves, as well as their purification and re-use.

$\circ \quad$ The level of waste generation will be in line with the existence in the area of facilities for collection, reduction, re-use and recycling.

$\circ \quad$ Systems for professional training and continuing education for workers and managers in the tourism sector, and

- Systems for the conversion of potential resources into tourism products and their structure in the region".

To wrap up the subject of prerequisites for the declaration of a tourist municipality, it merits indicating that said declaration is in competition, whether it be with the Autonomous Governmental Council (Murcia and Andalusia), or the Department in charge of tourism matters (Aragon; also Cantabria, although this is not expressly stated), and if Andalusia requires the City Council's plenary ruling affected by said declaration and Aragon expressly suspends the initiative of the affected municipality, the laws of Cantabria and Murcia say nothing on this subject, although it is possible to consider that "at first glance, it does not make sense to grant the qualification if it goes against local interests, as in a previous favorable agreement from the plenary meeting of the City Council". (BLANQUER CRIADO, 1999).

However, the laws on tourism structure for Aragon, Cantabria, Andalusia and Murcia are quite concise when it comes to the consequences resulting from the declaration of a tourist municipality, and in this respect, they indicate that said declaration, as we have stated above, will mean that those municipalities will benefit in a preferential way from the system of monetary grants and actions of fomentation and the promotion of tourism articulated by the autonomous government, with the already established intention of covering, above all, the levels of quantity and quality demanded when it comes to obligatory public services.

\section{b. Special issues in the regulation of the tourist municipality which appear in the laws of Galicia and Catalonia on tourism structure.}

The regulation of the tourist municipality covered by Galicia's and Catalonia's laws on tourism structureLaws $7 / 2011$, from October $27^{\text {th }}$, and $13 / 2002$, from June $21^{\text {st }}$, respectively-follow the general plan discussed in the previous section, specifically the requirements for the declaration and its effects, although they go into more detail in each of these questions, and furthermore, they bring together several extremes that were not anticipated by previous Autonomous Communities, including the possible loss of the tourist municipality title, and above all, the rights and obligations which correspond to these municipalities.

As far as criteria for granting the declaration of tourist municipality, which fall under the jurisdiction of the Galician Governmental Council and the Catalonian Government, depending on which law is being discussed, in both cases we go back to the traditional demands for a notable flow of the tourist population and of a significant number of hotel beds and second homes. What we find are quantitative variations between both Communities for the necessary calculations - that "the annual weighted average of the tourist population be more than $25 \%$ of the permanent population, and that the number of hotel beds and beds in second homes be more than $50 \%$ of the permanent population", according to the Galician law (Art. 27), or that the annual weighted average of the tourist population be more than the permanent population and that the number of hotel beds and beds in second homes be more than the permanent population, according to Art. 18, Section 1, of the Catalonian law. But it is also worth noting that the Galician and Catalonian laws foresee that it is possible to justify the declaration when there is an area within the city limits that has been declared a resource of essential interest to tourists (Catalonia) or that has proven to host a tourist event or service that results in the attraction of a number of tourists that is more than five times its population (Galicia). These demands may seem to be different, but in actuality, over and above the quantitative differences, they are the same. In Catalonia, an essential resource for tourists is that which has "the capacity to generate the most relevant flow of tourists and which strengthens the reality of Catalonia as an international tourist setting and promotes the country as a tourist destination" (Art. 5 of the Catalonian law). In any case, this possibility 
was not anticipated in the autonomous laws studied in the previous section, although the reality is that the important thing is the existence of an elevated tourist flow, and the reasons that drive that flow are secondary.

For this reason, perhaps it is much more important to note the possibility of losing the title of tourist municipality, which is predicted in the Galician and Catalonian laws on tourism structure (Arts. 30 and 22, respectively), but not in the autonomous laws analyzed previously. For this circumstance to come about, one of the following determining factors must be true: that the relevant City Council requests it; that the circumstances that motivated the declaration cease to be true; or that the City Council fails to provide the minimum services required by a tourist municipality.

Certainly, in our opinion, we consider that the possibility of losing the title of tourist municipality is quite small, at least it was before entering the economic crisis we find ourselves in now, which is having significant consequences in the maintenance of public services by all Public Administrations, and especially by City Councils, which currently lack the economic means necessary for providing the additional public services required by a tourist municipality. In this way, the second of the motives we referred to above for the loss of the title (that the circumstances that motivated the declaration cease to be true) is easy to understand, given that if the flow of tourists that led to the declaration is reduced or eliminated, for whatever reason, it is logical to conclude that the declaration of the tourist municipality no longer has meaning.

Nevertheless, for us, the first and third motives must be analyzed together and in a more detailed manner, precisely because we consider them to have the same point of origin. Logically, if tourist municipalities are no longer providing the minimum services required by their status, the consequence must be that they lose that status, since the main goal of having the title is to improve the quality of providing said services. But the possibility that the tourist municipality itself will renounce its title as such is not logical, and strikes one as strange, considering the theoretical advantages of everything that comes with said declaration. In our opinion, the fact that a municipality renounces its qualification as a tourist municipality is nothing more than the third motive on a list considered from a municipal perspective: the impossibility of providing the public services required by law, and in light of which, the City Council decides to renounce said declaration. We mustn't forget, as we will discuss in detail below, that one of the consequences of the declaration of a tourist municipality is the demand for a superior level of public municipal services, not only in quantity but in quality, and if the possibility is anticipated that this increase will be financed by acquiring the means for additional funding such as, for example, specific surcharges or taxes, the high cost that comes with these could result in the municipalities not following through with their obligations, especially in the current climate, where municipal tax income has fallen markedly, then it would be an extreme case, where the municipality itself requests the loss of its status as a tourist municipality, or the autonomous government decides to revoke said title. In any case, we continue to believe that this possibility is more theoretical than real. It may be true that City Councils are currently low on funds which are available for responding to the financial burden required to provide the obligatory extra public services that come with this title, but it is also true that said City Councils are promoting their tourist resources in an attempt to increase tourist flow, and as such, the revenue this generates, given that tourism is the economic sector least affected by the economic crisis, and with its fomentation, they are trying to compensate for the decrease in revenue that can be noted in other sectors, including construction and industry.

But, over and above the question of the loss of the tourist municipality title, for us, the biggest contribution made by the Galician and Catalonian laws is the one referred to in the list of all of the obligations and rights that come with said status. In this sense, it is worth clarifying that Andalusia also anticipates this question in the statute that develops the legal status of its tourist municipalities - the previously cited Andalusian Decree 158/2002, from May $28^{\text {th }}$ - but it does not do so in quite so explicit and clear a manner as do the Galician and Catalonian laws. Instead, its method is more incidental, laying out the details of the agreements that may be carried out for the improvement of those public services considered to be elements that will be valued in the declaration of a tourist municipality in Andalusia, and for this reason, we will focus on what has been indicated by Galicia and Catalonia.

In this respect, firstly, the laws of these Autonomous Communities bring together a list of obligatory services that must be provided by tourist municipalities and that constitute a bonus with respect to levels that have been established for all other municipalities (BLANQUER CRIADO, 1999). And what's more, what is relevant here is that this fact is a necessary imposition or consequence for the declaration of a tourist municipality, not just a mark 
of quality in the calculable services that already existed so that the declaration might be granted, as was the case in the self-governing laws previously studied, even though the tourist municipalities of those other Autonomous Communities have, in practice, the same or similar public services as those enumerated in the Galician and Catalonian laws, and the ultimate purpose of the existence of more and better municipal services in one or another law is identical, although the same cannot be said of the path that must be taken to achieve them.

As far as specific public services which are imposed by the Galician and Catalonian laws, we can turn, as a simple example, to Art. 28 of the Galician law, which indicates that, in addition to those anticipated by the general legislation of the local government, tourist municipalities must provide the following services: “...

a) Protection of public health and hygiene throughout the municipal territory, including beaches and coastlines.

b) Civil protection and the safety of citizens.

c) Promotion and protection of the City Council's tourist resources.

d) Signs providing information for tourists and general information.

e) Attention and orientation for tourists visiting information offices, which must remain open year-round and provide a qualified staff able to carry out this task.

f) A set-up that provides tourists with immediate access to the internet, located in the office of tourist information or in other consultation points which are open to the public.

g) Environmental duties which are their responsibility according to the laws in the sector.

h) The development of active policies on infrastructure and urbanism that favor surroundings which are pleasant and attractive to tourists, especially in historic quarters, conserving the architectural style of Galicia".

In addition to those listed previously, both laws include a generic clause making it obligatory to provide all the minimal services necessary for the permanent population supported by the municipality. As such, it is even more notable that the aimed-for goal, with the imposition of these public services, and in reality, with the declaration itself of tourist municipality, is the adaptation of the quantity and quality of said services for the real population that will benefit from them, in an attempt to solve the problem faced by said municipalities when they must provide minimal public services to a population that far exceeds that of the residents in said municipality, which are for those who, originally, were meant to receive those public services, and what's more, with the added difficulty that this increase is seasonal, making it necessary to take into consideration this characteristic when planning for the added public services that must be provided. For this reason, and in order to calculate the necessary services, said regulations indicate that the numbers must come from the sum of the weighted average of the seasonal population and the permanent population, anticipating the possibility of providing other complementary services, whether it be seasonally or with varying intensities, depending on tourist flow.

But providing the extra public services required by the Galician and Catalonian laws on tourist structure for tourist municipalities means, logically, that in both laws a series of rights and benefits is established for those who can choose them to make up for the obligations imposed upon them, which include those related to economics, with the intention of easing any financial problems caused by those services, and in this way, it is predicted that said municipalities (together with tourist agents who are active in said municipalities) will be the object of preferential treatment with regard to lines and measures of fomentation, whether they be economic or tourist-related, and the implementation of infrastructure and services; and in the sole case of Catalonia, that they will be able to impose specific taxes and surcharges. In addition, and together with the aforementioned items, another type of aptitude, like the participation of tourist municipalities in the elaboration of tourist plans and programs by inter-municipal and autonomous Administrations; in the activities of the autonomous Administration aimed at the interior and exterior promotion of tourism and the fomentation of tourism in said Communities; and in the policies of introduction or improvement of infrastructure and services that obviously affect tourism and are driven by the various departments of the autonomous Administration.

Nevertheless, in our opinion, it may not be possible for the cost of the public services imposed by the Galician and Catalonian laws on these municipalities to be defrayed only through the measures proposed in the regulations on this matter, especially because its most relevant aspect lies not in providing a set of public services 
linked specifically to tourism (tourism offices, signage, rescue teams and life-guard services on the beach, etc.), but rather the necessity of providing all the minimum obligatory services imposed by the legislation of the local government with a scope that is sufficient for the flow of tourists received. And while this may be, on the one hand, a natural and logical consequence of the characteristics that define them as tourist municipalities, it also means an economic load that is difficult for these municipalities to assume using the resources available to them in light of the current economic situation.

\section{c. Law 3/1998, from May $21^{\text {st }}$, on tourism in the Autonomous Community of Valencia, and its special regulation of the tourist municipality.}

The Autonomous Community of Valencia is one of the regions most visited by tourists to Spain, and in response to this situation, its law regulating tourism has anticipated a legal status for its tourist municipalities which is much more exhaustive and detailed than the Autonomous Communities we have just looked at, including those from Galicia and Catalonia.

In this way, that law would establish different criteria that allows for the differentiation between certain tourist municipalities and others, including that the flow of tourists is maintained throughout the year, or only at certain times of year; that the number of tourists be higher than the permanent population; whether or not they spend the night in the receiving municipality; that tourism constitute the base of its economy or that other complementary economic activities exist; that the capacity of tourist accommodation be higher than the number of primary residences; and that the capacity of these when added to the number of secondary homes be higher than the number of primary residences.

And with regard to the previous point, the Valencian law anticipates the existence, firstly, of tourist destinations - those which maintain a steady flow of overnight visitors year-round, the number of which is higher than the number of people officially registered as permanent residents, assuming that this activity forms the base of the local economy, and where the capacity of tourist accommodations is higher than the number of primary residences. Secondly, it anticipates the existence of vacation destinations - those that have a flow of overnight visitors only at certain times of year, the number of which exceeds the number of people officially registered as permanent residents, and which could have other complementary economic activity, and where the capacity of tourist accommodations added to the number of secondary residences is higher than the number of primary residences. And finally, it anticipates the existence of destinations which are tourist attractions - those which, because of their natural, monumental or socio-cultural attractions, or because of their relevance to a specific tourist market, receive at a certain time of year a significant number of visitors as compared to the number of permanent residents, without the need for these visitors to spend the night. For this reason, it has been suggested that the Autonomous Community of Valencia choose to anticipate the existence of three kinds of tourist municipalities, which deal with the special kind of tourism that characterizes each of these: tourism sustained throughout the year, vacation tourism and excursion tourism (BLANQUER CRIADO, 1999). As we will discuss below, this gives rise to a unique separate status for each of these classes.

Still, while the aforementioned point supposes an important variation with respect to the status of tourist municipalities anticipated by the previously studied regional laws, we can see that this is not the case with the generic requisites demanded by the Valencian law for the declaration and that, with the unique specificities of each type, they are quite similar to those we are already familiar with: flow of visitors in a significant proportion, high accommodation capacity and that tourist activity constitutes the base or main sector of the local economy. And in the same way, the Valencian law also establishes a series of general guidelines, which are already familiar, which are nothing more than the objectives sought out by the declaration of the tourist municipality, and which aim, through the development of tourist activity by these municipalities, to respect a set of values considered to be especially relevant. Specifically speaking, protection is sought for the environment and for the ecological values of the Autonomous Community of Valencia, for the cultural and traditional values of the local population, and for the preservation of the public and private goods that are related to tourism (in Art. 26, Section 1, of the previously cited Valencian law). 
Neither can reportable divergences be detected in the proceedings that must be followed for the declaration of a tourist municipality, as regulated in Art. 29 of the Valencian law, and as applied to the three instances described above, in which emphasis is given to the need for the application for said declaration to be agreed to by the relevant City Council, and above all, for the agreement to contain an indication of the steps that will be taken by the municipality to be considered as a tourist municipality (of the three kinds referenced above), corresponding with the Valencian government as to the concession or denial of said declaration.

Similarly, the Valencian law also regulates the possibility that the title of tourist municipality may be lost, in any of its forms. For disqualification to be agreed to by the Valencian government (Art. 31), it is necessary for one of the following causes to be true: substantial variation in the conditions that led to the declaration of the tourist municipality; noncompliance with any of the bases brought together in Art. 30 of the Valencian law on which the special status is based, having been derived from the qualification itself of a place as a tourist municipality (we will look more closely at this below); at the request of the municipality itself; or noncompliance on the part of municipalities of the unique conditions contained in the contract that can be drawn up with the autonomous Administration, as long as this is determined by said contracts. As you can see, radical variations cannot be appreciated here when compared to the motives we are already familiar with for the loss of the title of tourist municipality.

But we cannot wrap up without a brief pause to consider the most relevant aspect of the regulation of tourist municipalities in the Valencian law. We are referring to the specific legal status which, for each kind of tourist municipality anticipated by the law, is articulated in said law, derived, as we already know, from the specialties of the practice of tourism identified with each of these. This determines, as we can see below, that the applicable legal status is more strict for tourist municipalities that have been declared tourist destinations, is slightly more flexible for those declared vacation spots, and is clearly much less demanding for those declared tourist attractions.

In this way, Art. 30 of the Valencian law indicates that the special status of those declared tourist municipalities by way of tourist destination is based on the following: “...

a) Public services will be directed toward tourists, in general.

b) In the processing of municipal city systems, the prescriptive report of the Valencian Tourism Agency will be required, which will not have a binding effect.

c) Special attention will be paid to the identification of tourist centers and to the conservation and diversification of its attractions, whether natural or urban in nature.

d) They may subscribe to the agreements of the Valencian Generalitat to determine forms of cooperation and coordination, in the exercise of those powers that may be necessary for providing adequate special services, and if they are then established, in conformity with that established by this law".

For its part, the special status of tourist municipalities declared as such by way of vacation spot is based on the same items listed above, with the exception of the one defined in letter a), while those declared as such by way of tourist attraction are based solely on items c) and d) outlined above.

In conclusion, it is enough to say that the Valencian law anticipates the celebration of different kinds of agreements between the Valencian Generalitat and its tourist municipalities, focusing on the objective these municipalities have in common: to compensate for the additional financial strain that must be made by City Councils in tourist areas in those points that suffer from increases that cannot be covered by taxes (through the Agreement for financial compensation); to co-finance projects in tourist municipalities that have the goal of improving areas for tourist use or services that will lead to tourism products that are more competitive, and to spread the image of high quality attractions, while also pursuing the viability and sustainability of the development of tourism (through the Agreement for the adaptation of tourist municipalities); to promote and commercialize tourist municipalities, both on a national and international level, in order to achieve an acceptable market position with the goal of improving competitiveness (to be covered in the Agreement for competitiveness and communication). 


\section{AUTHOR INFORMATION}

Antonio Villanueva Cuevas, Ph.D. in Law and Degree in Law by University of Castilla-La Mancha. Assistant Profesor in Public Law at Public Law Department. Faculty of Social Sciences of Cuenca. University of Castilla-La Mancha (Spain). E-mail: Antonio.Villanueva@uclm.es

\section{REFERENCES}

1. BermejoVera, J (1984): “Administración Pública y Turismo”. REVL, nº 223, julio-septiembre.

2. Blanquer Criado, D. (1999): Derecho del Turismo.Tirant lo Blanch, Valencia.

3. Bosch, R., Pujol, Ll., Serra, J., y Vallespinos, F. (1998): Turismo y medio ambiente. Ed. Centro de Estudios Ramón Areces, Madrid.

4. $\quad$ Cebrián Abellán, M. (2005): Las relaciones de los Entes Locales con otras En tidades Públicas. Ed. Bayer Hnos., Barcelona.

5. Corno Caparrós, L. (1984): “El estatuto legal del municipio turístico: apuntes para una propuesta”. REDA, $n^{\circ}$ 42, abril-junio.

6. De Kadt, E. (1991): Turismo, ¿Pasaporte al desarrollo?. Ediciones Eudymion, Madrid.

7. Esteve Pardo, J. (1998): “Turismo y Administración Local”, en VV.AA: XI Congreso Italo-Español de Profesores de DerechoAdministrativo. Ed. Cedecs, Barcelona.

8. Fernández Rodríguez, C. (2005): Derecho Administrativo del Turismo. Ed. Marcial Pons, $3^{\text {a }}$ edición, Madrid/Barcelona.

9. Grifo Benedicto, M.A. (1999): “Colaboración interadministrativa en materia de turismo: mancomunidades, consorcios, conferencias sectoriales y convenios de colaboración”, en Blanquer Criado, D. (director): I Congreso Universitario de Turismo. Ed. Tirant lo Blanch, Valencia.

10. Guillén, M.A. (1999): "La distribución de competencias en materia turística entre el Estado, las Comunidades Autónomas y las Entidades Locales. Especial referencia a la Comunidad Valenciana”, en Blanquer Criado, D. (director): I Congreso Universitario de Turismo. Ed. Tirant lo Blanch, Valencia.

11. Jáimez Gago, Ma . I. (2010): Comentarios a la Ley de Ordenación del Turismo en Andalucía. Ed. Dykinson, Madrid.

12. Morell Ocaña, L. (1988): El régimen local español. Ed. Cívitas, Madrid.

13. Organización Mundial del Turismo (2011), Panorama OMT del Turismo Internacional, Edición 2011, extraídos de www.unwto.org, consultada el 25 de febrero de 2012.

14. Roca Roca, E., Ceballos Martín, Mª. M., y Pérez Guerra, R., (1998): La regulación jurídica del turismo en España. Universidad de Almería, Servicios de Publicaciones, Almería.

15. Roca Roca, E., y Pérez Martos, J. (1998): “Administración municipal y turismo”, publicado en VV.AA: XI Congreso Italo-Español de Profesores de DerechoAdministrativo. Ed. Cedecs, Barcelona.

16. Rodríguez-Arana Muñoz, J. (2001): "La distribución de competencias en materia de turismo". Documentación Administrativa, $n^{\circ} 259 / 260$, enero-agosto.

17. Suay Rincón, J., y Rodríguez González, M.P. (1999): "las competencias turísticas de los municipios. En particular, la categoría de los municipios turísticos", en Blanquer Criado, D. (director): I Congreso Universitario de Turismo. Ed. Tirant lo Blanch, Valencia.

18. Tudela Aranda, J. (1997): "Régimen local y turismo. Marco legal", en Tudela Aranda, J. (director): Estudios sobre el régimen jurídico del turismo. Diputación de Huesca, Huesca. 